\section{(C) OPEN ACCESS}

\title{
Intermediate C9orf72 alleles in neurological disorders: does size really matter?
}

\author{
Adeline S L Ng, ${ }^{1}$ Eng-King Tan ${ }^{2,3}$
}

- Additional material is published online only. To view please visit the journal online (http://dx.doi.org/10.1136/ jmedgenet-2017-104752).

${ }^{1}$ Department of Neurology, National Neuroscience Institute, Tan Tock Seng Hospital,

Singapore

${ }^{2}$ Department of Neurology, National Neuroscience Institute, Singapore General Hospital, Singapore

${ }^{3}$ Neuroscience and Behavioural Disorders, Duke-NUS Graduate Medical School, Singapore

\section{Correspondence to}

Dr Eng-King Tan, Department of Neurology, Singapore General Hospital, Block 1 Level 3, Outram Road, Singapore 169108, Singapore; gnrtek@ sgh.com.sg

Received 21 April 2017 Revised 25 May 2017

Accepted 26 May 2017 Published Online First 8 July 2017

\section{ABSTRACT}

C9orf72 repeat expansions is a major cause of familial frontotemporal dementia (FTD) and amyotrophic lateral sclerosis (ALS) worldwide. Sizes of $<20$ hexanucleotide repeats are observed in controls, while up to thousands associate with disease. Intermediate C9orf72 repeat lengths, however, remain uncertain. We systematically reviewed the role of intermediate C9orf72 alleles in C9orf72-related neurological disorders. We identified 49 studies with adequate available data on normal or intermediate C9orf72 repeat length, involving subjects with FTD, ALS, Parkinson's disease (PD), atypical parkinsonism, Alzheimer's disease (AD) and other aetiologies. We found that, overall, normal or intermediate C9orf72 repeat lengths are not associated with higher disease risk across these disorders, but intermediate allele sizes appear to associate more frequently with neuropsychiatric phenotypes. Intermediate sizes were detected in subjects with personal or family history of FTD and/ or psychiatric illness, parkinsonism complicated by psychosis and rarely in psychiatric cohorts. Length of the hexanucleotide repeat may be influenced by ethnicity (with Asian controls displaying shorter normal repeat lengths compared with Caucasians) and underlying haplotype, with more patients and controls carrying the 'risk' haplotype rs3849942 displaying intermediate alleles. There is some evidence that intermediate alleles display increased methylation levels and affect normal transcriptional activity of the C9orf72 promoter, but the 'critical' repeat size required for initiation of neurodegeneration remains unknown and requires further study. In common neurological diseases, intermediate C9orf72 repeats do not influence disease risk but may associate with higher frequency of neuropsychiatric symptoms. This has important clinical relevance as intermediate carriers pose a challenge for genetic counselling.

\section{INTRODUCTION}

The hexanucleotide repeat GGGGCC expansion within the first intron of the C9orf72 gene on chromosome 9p21 has been associated with amyotrophic lateral sclerosis (ALS) and frontotemporal dementia (FTD), ${ }^{12}$ accounting for $\sim 40 \%$ of familial ALS, $30 \%$ of familial FTD and $\sim 8 \%$ of sporadic ALS cases in predominantly Caucasian populations. ${ }^{3}$ Most healthy individuals carry up to 25 repeats, with more than half carrying only two repeats, while pathogenic expansions of hundreds ${ }^{2}$ to several thousands have been reported in FTD and ALS. ${ }^{14}$ Other repeat expansion disorders have explored the potential effect intermediate alleles have on conferring disease: in Huntington's disease (HD), intermediate CAG lengths overlapped with patients with $\mathrm{HD}$ on behavioural measures ${ }^{5}$ and pathological evidence of HD was found in patients with intermediate (range 27-35) CAG repeats. ${ }^{5}$ Spinocerebellar ataxia 2 patients with apparently sporadic disease have shown intermediate CAG repeats of 22-35 units in the ATXN2 locus. ${ }^{6}$

In C9orf72-related disease, a repeat length of $>30$ has typically been defined as pathogenic, ${ }^{2}$ mainly due to technical limitations of the repeat-primed PCR (rp-PCR) technique. While cell and Drosophila models indicate that expression of $>30$ repeats are sufficient to cause neurodegeneration, ${ }^{7}$ it remains unknown how many repeats are truly needed to cause disease. Small repeat sizes of 20-22 were reportedly pathogenic in FTD, ${ }^{8}$ and the clinical phenotype of ALS cases with 20-30 repeats appear similar to those with $>30$ repeats. ${ }^{9}$ Given the conflicting evidence concerning pathogenicity of intermediate repeat numbers, we sought to summarise the current literature and provide insights into the potential role intermediate C9orf72 repeats may play (if any) in modulating clinical disease.

\section{Review of the current literature}

We conducted a PubMed and Google Scholar search for all relevant full-text studies and articles using search terms including 'C9orf72', 'intermediate alleles' and 'repeat size' in neurological diseases. Only English articles with available data (including online supplementary material) on C9orf72 allele lengths in normal and intermediate repeat ranges were included. Methods used by each study for repeat-length analysis (Southern blotting, rp-PCR and fluorescent fragment length analysis) are listed in the online supplementary table files.

Intermediate C9orf72 repeats do not appear to influence disease risk or clinical characteristics in nonexpansion cases and controls

We identified 49 studies on intermediate alleles in neurodegenerative diseases, including 13 studies with FTD-spectrum cases, and 16 studies with ALS cases. Eight studies found no significant difference in mean repeat lengths between expansion-negative FTD cases and controls. ${ }^{10-17}$ Sporadic FTD cases appear to show similar allele frequency distribution as controls, with the two-unit repeat being the most common, followed by the 5-repeat, 6-repeat, 7-repeat or 8-repeat unit. ${ }^{12-19}$ Repeat range was higher in a Dutch study of 363 FTD patients where 
$10 \%$ had an FTD-ALS syndrome, with FTD cases showing mean (SD) size of $13.9 \pm 14.0$ repeats (range 1-64) compared with $9.1 \pm 6.8$ (range 2-35) in controls. Notably, a proband in an FTD-ALS family carried 26 repeats, with affected family members carrying a repeat range of $8-29 .^{20}$ Pathologically confirmed corticobasal degeneration $(n=18)$ and progressive supranuclear palsy (PSP) $(n=177)$ cases carried repeat lengths ranging from 2 to 22, with one clinically diagnosed 'typical' PSP case with family history of dementia and parkinsonism carrying 27 repeats. ${ }^{21}$ In sporadic ALS, repeat length and allele frequency distribution appear to be similar between cases and controls. ${ }^{12} 1322-28$ This was similarly seen in familial ALS, ${ }^{26} 28{ }^{29}$ but a Japanese study reported slightly longer repeat lengths in familial ALS non-expansion samples $(5.90 \pm 3.91$ repeats) carrying the risk ' $A$ '-allele compared with those without (3.36 \pm 2.13 repeats). ${ }^{27}$ In sporadic ALS, no correlation between lengths of the shortest, longest and sum of both alleles without the repeat expansion with age of onset, survival or region of disease onset was seen. ${ }^{24}$

Nineteen studies of PD and atypical parkinsonism cases were identified. Nine PD studies reported range of repeat lengths similar between PD cases and controls, ${ }^{14} 161730-35$ with no correlation between repeat length and family history or age of disease onset. ${ }^{35}$ No evidence of association between repeat length and age-at-onset or risk of PD, essential tremor (ET) or restless legs syndrome after correction for multiple testing $(p<0.0028)$ was seen, ${ }^{31}$ and the length of the longest non-expanded repeat allele did not correlate with age at onset $(p=0.11)$ in PD. ${ }^{32}$ None of 29 LRRK2 mutation carriers screened for C9orf72 had an expanded or intermediate allele ( $<11$ repeats). ${ }^{16}$ Twenty-three cases of classical PD harbouring larger-than-normal alleles (21-38 repeats) have been reported, ${ }^{14} 163436$ including two with severe dementia ${ }^{16}$ and one young-onset 'typical' PD, ${ }^{14}$ suggesting that $\mathrm{C} 9$ orf72 intermediate repeats may contribute to risk for PD and ET plus parkinsonism. ${ }^{34}$ However, intermediate allele frequency appeared to be similar to that of controls $(2.2 \%$ of PD vs $2.9 \%$ in controls). ${ }^{30}$ Using a lower cut-off of $<20$ for intermediate repeat length, Nuytemans et al reported more intermediate alleles in PD (2\%) compared with controls (0.3\%), with intermediate repeats significantly associating with increased PD risk $(p=0.008)$ at an OR of 9.6 , but with an extremely wide CI due to rarity of the intermediate repeat. Thirteen intermediate repeat patients demonstrated a classical PD phenotype responsive to levodopa, with no suggestion of ALS or family history of ALS. ${ }^{34}$ Overall, the small number of cases reported and the occurrence of intermediate repeats in some controls suggests that C9orf72 intermediate repeats are most likely a susceptibility factor or arise from phenotypic heterogenity, rather than causal for PD. ${ }^{34}$ This was confirmed when no interm ediate or expanded repeats was found in an autopsy-confirmed PD data set. ${ }^{37}$ Overall, only a small number of large expansions $(>30$ repeats) have been found in $\mathrm{PD}$, suggesting that $>30$ repeats are not a common cause of PD (0.2\% of 3500 tested). ${ }^{37}$ Finally, a meta-analysis by the Genetic Epidemiology of Parkinson's disease (GEo-PD) consortium cohort of 7494 patients with PD revealed a small increase in PD risk with an increasing number of $\mathrm{C} 9$ orf72 repeats, but no robust association was detected. The cohort size suggested an association for the 10-unit repeat and for pooled alleles of $\geq 17$ repeats in increasing PD risk, but this did not reach significance after correction for multiple testing. ${ }^{38}$

In nine atypical parkinsonian disease studies, including pathologically confirmed multiple system atrophy (MSA) ${ }^{2139}$ and diffuse Lewy body dementia (DLB) ${ }^{4041}$ cases, pathogenic expansions were rare, and repeat range of non-expansion alleles were similar to that of controls. ${ }^{14172130333942}$ Two pathologically diagnosed DLB samples carried 32 repeats and one with 33 repeats, although no details were provided regarding presence or absence of TDP43 pathology in these patients. ${ }^{41}$ Intermediate repeats (20-29 units) were significantly more frequent in atypical parkinsonism cases than controls $(\mathrm{p}<0.034)$ and were seen in four $(4.3 \%)$ female patients (with 20, 22, 23 and 28 repeats), three of whom had non-classical atypical parkinsonism. ${ }^{42}$ PSP patients with intermediate repeat lengths of 26 and 30 were reported, but it is unclear if the repeat expansions and clinical symptoms are related. ${ }^{33}$ Five studies of Alzheimer's disease (AD), including one study with $80 \%$ of subjects under age $65,{ }^{43}$ were included. ${ }^{163243-45}$ Within the normal and intermediate repeat range, higher repeat numbers did not increase risk for $\mathrm{AD},{ }^{16}{ }^{32}$ or interact with apolipoprotein E (APOE) genotype. ${ }^{44}$ No significant difference in the frequency of short $(<7)$ and intermediate $(>7)$ repeats was seen between $\mathrm{AD}$ and mild cognitive impairment (MCI) subjects and controls; MCI cases with intermediate repeats were not at greater risk for $\mathrm{AD},{ }^{45}$ and intermediate allele sizes had no influence on cerebrospinal fluid core AD biomarkers. ${ }^{45}$

\section{Intermediate C9orf72 alleles may be associated with a higher} frequency of psychiatric symptoms

Four FTD families were reported to carry 20-repeat or 22-repeat alleles associated with the surrogate founder haplotype, segregating consistently in all affected siblings, with unaffected siblings carrying wild-type alleles (two to nine repeats). ${ }^{8}$ Most of the nine carriers with $>20$ to $>30$ repeats had extended periods of psychiatric symptoms and subjective cognitive complaints before clear neurological deterioration. In other studies, a 29-repeat allele was found in a patient from a Dutch family with C9orf72-related FTD-ALS, ${ }^{20}$ and four patients with limb-onset ALS with intermediate repeats (range 20-22) had lower mean (SD) age of diagnosis compared with patients with $<20$ repeats $(47.6 \pm 15.9$ vs $62.8 \pm 11.2$ years). ${ }^{9}$ Both patients in the latter study with 22 repeats exhibited cognitive and behavioural impairment similar to larger expansions and had family history of FTD, while two patients with 20 and 21 repeats had family history of dementia and psychiatric illness. In atypical PD or PD with psychosis, intermediate expansions (20-29) were detected in three female cases with atypical parkinsonian syndromes (severe rigid akinetic parkinsonism) and neuropsychiatric symptoms including schizoaffective psychosis and an FTD-like dementia. ${ }^{42}$ Unfortunately, these cases did not have pathological diagnosis. In schizophrenia, the pathogenic repeat expansion was detected in only two patients $(0.67 \%)$, but the estimated number of repeats in controls appeared lower (2-5 units) than in schizophrenic patients without the expansion (2-30 units). ${ }^{46}$ Only 4/130 (3\%) patients with psychosis from the Northern Finland Birth Cohort had intermediate repeat sizes (17-26 units). ${ }^{47}$ An Irish psychosis cohort found seven samples with $>22$ repeats including two schizophrenia cases (with 28 and 27 repeats) and five controls (with 23-26 repeats), but with no overall evidence of association between repeat length and schizophrenia. ${ }^{48}$ Unfortunately, detailed phenotypic description of these intermediate carriers remains of variable quality across studies, both for motor and non-motor signs. Overall, it remains possible that the pathological cut-off for C9orf72 expansions is disease dependent, modulated by unknown or individual genetic factors, with intermediate allele sizes potentially predisposing to neuropsychiatric sequelae.

Repeat lengths in the normal and intermediate range may be haplotype dependent

The full background 82-SNP 'founder' haplotype (r) from which the C9orf72 expansion arose is present in almost all 


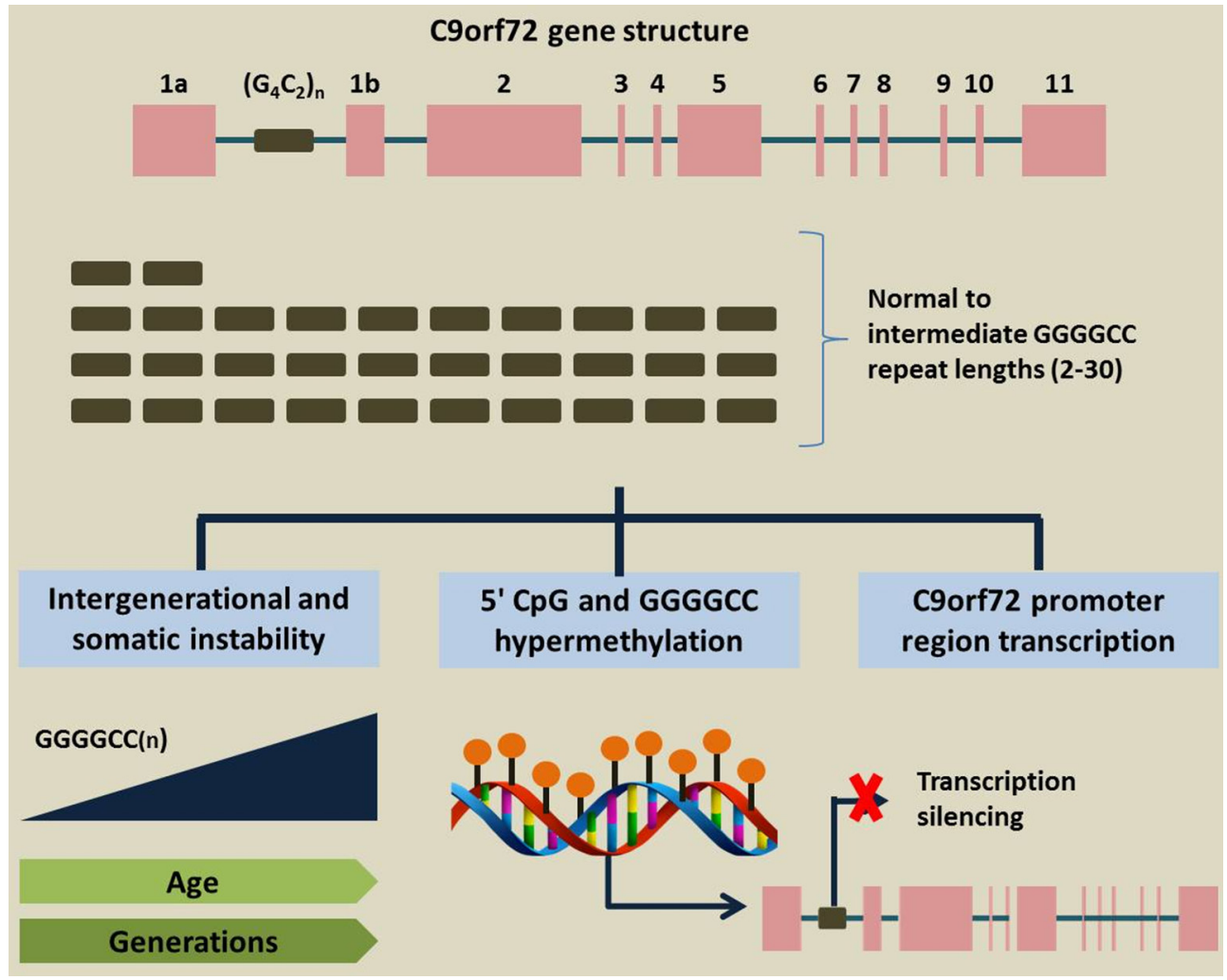

Figure 1 Possible mechanistic pathways involving intermediate C9orf72 alleles.

populations studied in the ' 1000 Genome' database ( $15 \%$ of European controls). ${ }^{49}$ Nearly $50 \%$ of individuals with non-(r) haplotypes carry up to two copies compared with only 5\% of those with the (r) haplotype, who carry eight repeats or more. In Irish psychosis patients, $78 \%$ of samples with $>6$ repeats carried the founder haplotype compared with only $3 \%$ with $<6$ repeats. ${ }^{48}$ A meta-analysis of genome-wide association study data from five European populations reduced the ' $r$ ' haplotype to a common 20-SNP 'risk' haplotype (rs3849942, allele 'A') in significant association with FTD and ALS, ${ }^{50}$ and controls have shown significantly longer median repeat length (eight units) on the 'risk' haplotype compared with the wild-type haplotype (rs3849942 allele 'G'; 2 units). ${ }^{1}$ In PD, the rs3849942 allele was confirmed in $100 \%$ of all intermediate carriers, with the tagging (T) allele seen in $95 \%$ of all individuals with $\geq 8$ repeats, versus $10 \%$ in those with $<8$ repeats. ${ }^{34}$ Pathologically confirmed PD cases identified the T-allele in $40 \%$ of patients, and $>90 \%$ of T-allele carriers carried $>8$ repeats. ${ }^{37}$ Japanese ALS patients carrying at least one rs3849942 allele had significantly longer repeats than those without. ${ }^{27}$

Possible mechanistic pathways involving intermediate alleles Intermediate alleles are 'predisposing' alleles that lead to large expansions over many subsequent generations

C9orf72 alleles at $<20$ repeats appear stable between generations, while small expansions (20-150 repeats) are susceptible to unfaithful inheritance ${ }^{4}$ or somatic instability (figure 1$) .^{20}$ Intermediate repeats may be prone to gaining and losing copies as opposed to longer repeats whose length mostly increases. ${ }^{34}$ In French control samples, the largest repeat (22 units) changed size twice in the same family with all intergenerational changes occurring from a starting length of $>10$ repeats on the same rs3849942A 'risk' haplotype, suggesting that either repeat length and/or risk haplotype confer instability. ${ }^{4}$ Increased frequency of short indels in the GC-rich low complexity sequence adjacent to the expanded repeat in C9orf72 carriers suggests that subsequent pathological expansion may be due to replication slippage. ${ }^{51}$ However, the younger generation in 20 families of index patients with intermediate alleles of up to 22 units did not show longer intermediate repeat lengths or pathological expansions, suggesting that intermediate length might be 'predisposing' rather than 'pre-mutation' alleles for further stepwise expansion over many generations. ${ }^{51}$ Large-scale multigenerational cohorts will be required to determine how many repeats constitute such an allele.

Intermediate alleles may display increased methylation but at lower levels than large expansions

Hypermethylation of the CpG island 5' to the C9orf72 GGGGCC repeat has been associated with expansion in ALS, but methylation changes have not been detected in either normal or intermediate alleles (up to 43 repeats), which questioned the cut-off of 30 repeats for pathogenicity. ${ }^{52}$ Comparison of methylation levels of homozygous normal intermediate repeat carriers (I/I) (7-24 units) with homozygous normal short repeat carriers (S/S) (2-6 units) in ALS and FTD-ALS demonstrated a slight but significant increase in methylation from I/I samples compared with S/S samples in both patient and control groups, with higher methylation levels in I/I carriers derived mostly from carriers with at least one allele of $>8$ units. Intermediate wild-type alleles of expansion carriers were also significantly more methylated than normal short wild-type alleles $(\mathrm{p}<0.0001)$. Notably, 5' $\mathrm{CpG}$ and GGGGCC methylation was significantly higher in brain than in the blood of patients with normal repeats $(\mathrm{p}<0.0001) .{ }^{53}$ Given that the degree of methylation remained very low $(<5 \%)$ in samples without long expansions versus $\sim 10 \%$ in expansion 


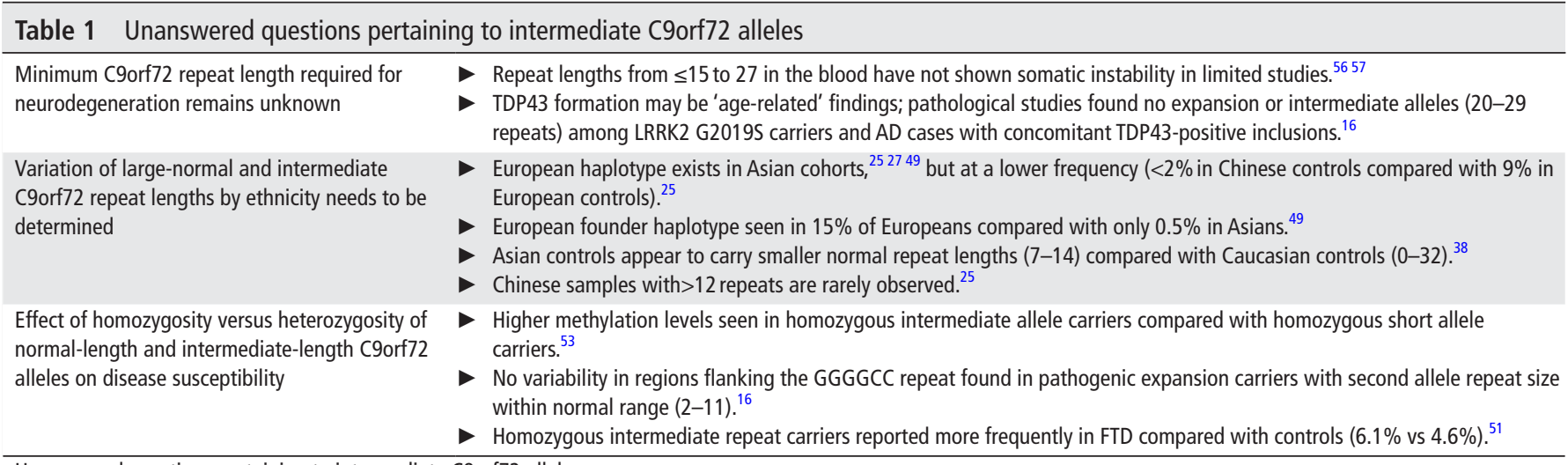

Unanswered questions pertaining to intermediate C9orf72 alleles.

FTD, frontotemporal dementia; LRRK2, leucine-rich repeat kinase; TDP43, TAR DNA-binding protein 43.

carriers, further work needs to be done to elucidate any epigenetic modulation in intermediate C9orf72 allele carriers and the minimum repeat cut-off required for this to occur.

\section{Intermediate alleles affect normal transcriptional activity of the C9orf72 promoter}

In vitro reporter gene expression studies have shown significantly decreased transcriptional activity of the $\mathrm{C} 9$ orf 72 promoter with increasing number of normal and intermediate repeats, with a 24 -unit containing promoter showing $>50 \%$ reduction in transcription compared with 2 units on the wild-type allele. ${ }^{51}$ In human kidney and neuroblastoma cell lines (HEK293T cells), intermediate repeats (7-24) have shown significantly decreased C9orf72 promoter activity compared with normal short repeats (2-6 units), ${ }^{53}$ with lower transcriptional activity appearing more prominent in the presence of small deletions flanking the GGGGCC unit. Overall, these findings suggest that increasing repeat length can lead to decreased promoter activity via increased methylation of $\mathrm{CpG}$ sequences in larger repeats, with transcriptional silencing of the promoter. ${ }^{53}$

\section{UNANSWERED QUESTIONS}

\section{Minimum repeat length in blood corresponding with large expansions in CNS tissue}

The minimum repeat length required for disease is not known due to somatic instability, with variation in length between tissues, even within the same individual, complicating genotypephenotype studies (table 1). ${ }^{54}$ Subtle differences in repeat length within the same patient and between monozygotic twins strongly suggest that random, stochastic expansion events may occur during cell division, resulting in somatic and/or germline mosaicism contributing to intraindividual and interindividual repeat variation. ${ }^{55}$ Limited data show that repeat lengths from $\leq 15$ to 27 in the blood do not show somatic instability. ${ }^{567}$ Postmortem studies involving a wide range of CNS tissue examination in cases with large-normal and intermediate repeats lengths in peripheral blood are needed.

\section{Variation of large-normal and intermediate repeat lengths by ethnicity}

In the GEO-PD consortium, Asian controls appeared to carry smaller normal repeat lengths (7-14) compared with Caucasian controls $(0-32) .^{38}$ Caucasian alleles frequently contain up to 43 repeats, ${ }^{42}$ but in Chinese samples, $>12$ repeats are rarely observed. ${ }^{25}$ The European haplotype does exist in Asian cohorts $^{252749}$ but at a lower frequency $(<2 \%$ in Chinese controls compared with $9 \%$ in European controls). ${ }^{25}$ Data from the 1000 -genomes project estimate the frequency of the European founder haplotype in 15\% of Europeans compared with only $0.5 \%$ in Asians. ${ }^{49}$ Two Han Chinese ALS expansion carriers had methylation of the upstream $\mathrm{CpG}$ island but did not carry the founder haplotype, ${ }^{25}$ implying that C9orf72 alleles may undergo dynamic mutation independent of the European haplotype. This 'Chinese haplotype' was also associated with $\geq 8$ repeats $(20 \%$ vs $8 \%$ in other haplotypes), implying that both the Scandinavian and Chinese haplotypes may confer repeat length instability. ${ }^{25} \mathrm{It}$ remains possible that the haplotype may be genetic background for expansion carriers and not necessarily associated with the expansion, as none of 53 FTD patients recruited in the USA with diverse ethnic backgrounds shared the exact same Scandinavian risk haplotype. ${ }^{11}$ Multicentre collaborative efforts pooling Asian samples are needed to determine if the lower incidence of pathogenic C9orf72 expansions in multiple Asian cohorts is due to shorter Asian repeat lengths that may be at lower risk for instability.

\section{'Critical' repeat size required for initiation of neurodegeneration remains unknown}

Toxic gain-of-function by dipeptide repeat proteins (DPRs) and/ or RNA foci generated by unconventional repeat-associated non-ATG translation and TDP43 inclusions remains a possible mechanism for C9orf72 pathogenesis. ${ }^{3}$ Cognitively normal cases from the Queen Square Brain Bank screened for C9orf72 expansions found one 84 year-old subject with intermediate repeats (20-40) showing TDP43-positive lesions, sense and antisense RNA foci in the frontal cortex and p62-positive inclusions containing all five DPRs, but more sparsely compared with FTD cases with large expansions. ${ }^{58}$ DPR inclusions and RNA foci were, however, notably absent in two pathologically normal cases with 20 repeats, suggesting it may not be long enough to trigger the entire disease cascade necessary for TDP43 pathology. TDP43 formation may also represent 'age-related' phenomena, and pathological studies have found no expansion or intermediate alleles (20-29 repeats) among LRRK2 G2019S carriers and $\mathrm{AD}$ cases who had concomitant TDP43-positive inclusions. ${ }^{16}$

\section{Effect of homozygosity versus heterozygosity of normal and intermediate alleles}

In pathogenic expansion carriers, repeat size of the second allele appear to be within the normal range $(2-11)$ and unlikely to contribute to disease given that no variability in the regions flanking the hexanucleotide repeat was found. ${ }^{16}$ Homozygous 
Table 2 Priorities for research into C90RF72 intermediate alleles

Address methodological differences

Deciphering role of DNA composition in expanded repeats

Developing novel genotyping methods

Adopting a multigeneration intrafamilial approach

Detailed clinical phenotyping

Developing better cellular models of C9orf72

Longitudinal cohort study

Multicentre study approach for optimising sample size
Repeat-primed PCR should be combined with Southern blot for estimation of repeat size and not be used in isolation. Sequencing should be used for smaller repeat sizes.

The 'critical repeat size' may not be key, but rather the exact composition within the expanded repeats, including the possibility of repeat interruptions.

Developing the ability to conduct a fast comprehensive systematic screen for repeat expansions on a genomewide level.

Phenotype-genotype correlations within large multigeneration families can minimise the effect of heterogeneity in genetic background and confounders.

Detailed clinical and neuropsychological profiling in symptomatic and asymptomatic carriers and healthy controls for accurate genotype-phenotype correlations.

Patient-derived induced pluripotent stem cell neurons harbouring different repeat sizes and transgenic nonhuman primates can provide additional insights.

A longitudinal cohort including subjects with intermediate alleles with long-term follow-up supported by detailed clinical, neuroimaging and biochemical evaluation.

A global multicentre approach with standardised protocols and a centralised genotyping laboratory will aid in identifying rare associations, elucidate variation according to ethnicity and minimise diagnostic errors. intermediate repeat carriers have been reported more frequently in FTD subjects compared with controls $(6.1 \%$ vs $4.6 \%),{ }^{51}$ but in PD cases with $>20$ repeats, all but two of 407 intermediate repeat carriers were heterozygous for the intermediate allele and a low copy number allele, with only one sample homozygous for intermediate repeats. This proband carried three different maximum intermediate repeat alleles in two offspring and herself, developing ET at age 20 with mild parkinsonism at 97 years old. ${ }^{34}$ As described earlier, higher methylation levels were seen in homozygous intermediate allele compared with homozygous short allele carriers. ${ }^{53}$

\section{FUTURE DIRECTIONS AND CONCLUSIONS}

Further steps for elucidating the uncertain role(s) of intermediate C9orf72 hexanucleotide repeats include (table 2): (1) common centralised genotyping methodology for comparing allele size accurately. The common rp-PCR method cannot reliably distinguish between repeat sizes $>30-60$ units $^{2}$ and is inadequate when used without confirmation by Southern blot, as confirmed by a masked study at 14 laboratories showing lack of accuracy when rp-PCR was used in isolation. ${ }^{59}$ Southern blot analysis, however, is affected by age and somatic heterogeneity, hence for smaller range repeats, sequencing to determine the actual size may be more useful and will also provide the actual DNA composition of the repeat; additionally, Southern blot results should be interpreted in conjunction with recent improved rp-PCR techniques ${ }^{60} ;$ (2) deciphering DNA composition within expanded repeats will be important, as the 'critical repeat size' may not be key, but rather the exact composition within the expanded repeats, including the presence or absence of stabilising interruptions; (3) developing novel genotyping methods for elucidating the role of other GGGGCC loci and repeat expansions in the human genome as well as other pathogenic genes in modulating the risk of C9orf72-linked disorders; (4) developing a fast comprehensive systematic screen for repeat expansions on a genome-wide level; (5) development of novel cellular and in vivo models given that current ones do not fully recapitulate clinical disease. The wide range of pathogenic GGGGCC repeat sizes and the large size of the repeat region, combined with the fact that it is entirely GC makes the generation of cell models technically difficult. Patient-derived induced pluripotent stem cell neurons harbouring different repeat sizes and transgenic non-human primates can provide additional insights.

Many studies involved retrospectively collected samples or were based on limited clinical information, rendering clinical phenotyping of intermediate allele carriers less accurate. Efforts to ensure detailed clinical and neuropsychological profiling in symptomatic and asymptomatic carriers and healthy controls remains vital; accurate phenotype-genotype correlations within large multigeneration families can also aid in minimising the effect of confounders and genetic background heterogeneity. Finally, in genetic association studies, sample size remains critical. Thus, a global multicentre approach with standardised clinical and neuroimaging protocols and a centralised genotyping laboratory will aid in identifying rare associations and minimise diagnostic errors, as well as investigate differences according to ethnicity, potentially unravelling new clues concerning the role of intermediate C9orf72 alleles.

Contributors A SL Ng conducted the literature search and drafting of the manuscript. EK Tan revised the manuscript for intellectual content and provided the outline for the draft. A SL Ng and EK Tan drafted and approved the manuscript.

Funding A SL Ng is supported by the Singapore Ministry of Health's National Medical Research Council (NIG grant) and the SingHealth Foundation Award (PRISM grant). EK Tan is supported by the Singapore Ministry of Health's National Medical Research Council (STaR and Parkinson's Disease TCR grants).

Competing interests None declared.

Provenance and peer review Commissioned; externally peer reviewed.

Open Access This is an Open Access article distributed in accordance with the Creative Commons Attribution Non Commercial (CC BY-NC 4.0) license, which permits others to distribute, remix, adapt, build upon this work non-commercially, and license their derivative works on different terms, provided the original work is properly cited and the use is non-commercial. See: http://creativecommons.org/ licenses/by-nc/4.0/

(C) Article author(s) (or their employer(s) unless otherwise stated in the text of the article) 2017. All rights reserved. No commercial use is permitted unless otherwise expressly granted.

\section{REFERENCES}

1 DeJesus-Hernandez M, Mackenzie IR, Boeve BF, Boxer AL, Baker M, Rutherford NJ Nicholson AM, Finch NA, Flynn H, Adamson J, Kouri N, Wojtas A, Sengdy P, Hsiung GY, Karydas A, Seeley WW, Josephs KA, Coppola G, Geschwind DH, Wszolek ZK, Feldman H, Knopman DS, Petersen RC, Miller BL, Dickson DW, Boylan KB, Graff-Radford NR, Rademakers R. Expanded GGGGCC hexanucleotide repeat in noncoding region of C9ORF72 causes chromosome 9p-linked FTD and ALS. Neuron 2011;72:245-56.

2 Renton AE, Majounie E, Waite A, Simón-Sánchez J, Rollinson S, Gibbs JR, Schymick JC, Laaksovirta H, van Swieten JC, Myllykangas L, Kalimo H, Paetau A, Abramzon Y, Remes AM, Kaganovich A, Scholz SW, Duckworth J, Ding J, Harmer DW, Hernandez DG, Johnson JO, Mok K, Ryten M, Trabzuni D, Guerreiro RJ, Orrell RW, Neal J, Murray A, Pearson J, Jansen IE, Sondervan D, Seelaar H, Blake D, Young K, Halliwell N, Callister JB, Toulson G, Richardson A, Gerhard A, Snowden J, Mann D, Neary D, Nalls MA, Peuralinna T, Jansson L, Isoviita VM, Kaivorinne AL, Hölttä-Vuori M, Ikonen E, Sulkava R, Benatar M, Wuu J, Chiò A, Restagno G, Borghero G, Sabatelli M, Heckerman D, Rogaeva E, Zinman L, Rothstein JD, Sendtner M, Drepper C, Eichler EE, 
Alkan C, Abdullaev Z, Pack SD, Dutra A, Pak E, Hardy J, Singleton A, Williams NM, Heutink P, Pickering-Brown S, Morris HR, Tienari PJ, Traynor BJ. ITALSGEN Consortium. A hexanucleotide repeat expansion in C90RF72 is the cause of chromosome 9p21linked ALS-FTD. Neuron 2011;72:257-68.

$3 \mathrm{Ng} \mathrm{AS}$, Rademakers R, Miller BL. Frontotemporal dementia: a bridge between dementia and neuromuscular disease. Ann N Y Acad Sci 2015;1338:71-93.

4 Beck J, Poulter M, Hensman D, Rohrer JD, Mahoney CJ, Adamson G, Campbell T, Uphill J, Borg A, Fratta P, Orrell RW, Malaspina A, Rowe J, Brown J, Hodges J, Sidle K, Polke JM, Houlden H, Schott JM, Fox NC, Rossor MN, Tabrizi SJ, Isaacs AM, Hardy J, Warren JD, Collinge J, Mead S. Large C9orf72 hexanucleotide repeat expansions are seen in multiple neurodegenerative syndromes and are more frequent than expected in the UK population. Am J Hum Genet 2013:92:345-53.

$5 \mathrm{Ha}$ AD, Jankovic J. Exploring the correlates of intermediate CAG repeats in Huntington disease. Postgrad Med 2011;123:116-21.

6 Kim JM, Hong S, Kim GP, Choi YJ, Kim YK, Park SS, Kim SE, Jeon BS. Importance of low-range CAG expansion and CAA interruption in SCA2 Parkinsonism. Arch Neurol 2007;64:1510-8.

7 Xu Z, Poidevin M, Li X, Li Y, Shu L, Nelson DL, Li H, Hales CM, Gearing M, Wingo TS, Jin P. Expanded GGGGCC repeat RNA associated with amyotrophic lateral sclerosis and frontotemporal dementia causes neurodegeneration. Proc Natl Acad Sci U SA 2013;110:7778-83.

8 Gómez-Tortosa E, Gallego J, Guerrero-López R, Marcos A, Gil-Neciga E, Sainz MJ, Díaz A, Franco-Macías E, Trujillo-Tiebas MJ, Ayuso C, Pérez-Pérez J. C9ORF72 hexanucleotide expansions of 20-22 repeats are associated with frontotemporal deterioration. Neurology 2013;80:366-70.

9 Byrne S, Heverin M, Elamin M, Walsh C, Hardiman O. Intermediate repeat expansion length in C9orf72 may be pathological in amyotrophic lateral sclerosis. Amyotroph Lateral Scler Frontotemporal Degener 2014;15:148-50.

10 Dobson-Stone C, Hallupp M, Bartley L, Shepherd CE, Halliday GM, Schofield PR, Hodges JR, Kwok JB. C9ORF72 repeat expansion in clinical and neuropathologic frontotemporal dementia cohorts. Neurology 2012;79:995-1001.

11 Ferrari R, Mok K, Moreno JH, Cosentino S, Goldman J, Pietrini P, Mayeux R, Tierney MC, Kapogiannis D, Jicha GA, Murrell JR, Ghetti B, Wassermann EM, Grafman J, Hardy J, Huey ED, Momeni P. Screening for C9ORF72 repeat expansion in FTLD. Neurobiol Aging 2012;33:1850.e1-1850.e11.

12 Itzcovich T, Xi Z, Martinetto H, Chrem-Méndez P, Russo MJ, de Ambrosi B, Uchitel OD, Nogués M, Silva E, Rojas G, Bagnatti P, Amengual A, Campos J, Rogaeva E, St George-Hyslop P, Allegri R, Sevlever G, Surace El. Analysis of C9orf72 in patients with frontotemporal dementia and amyotrophic lateral sclerosis from Argentina. Neurobiol Aging 2016;40:192.e13-192.e15.

13 Jiao B, Tang B, Liu X, Yan X, Zhou L, Yang Y, Wang J, Xia K, Shen L. Identification of C9orf72 repeat expansions in patients with amyotrophic lateral sclerosis and frontotemporal dementia in mainland China. Neurobiol Aging 2014;35:936.e19-936. e22.

14 Lin CH, Chen TF, Chiu MJ, Lin HI, Wu RM. Lack of c9orf72 repeat expansion in taiwanese patients with mixed neurodegenerative disorders. Front Neurol 2014;5:59.

15 Rutherford NJ, Heckman MG, DeJesus-Hernandez M, Baker MC, Soto-Ortolaza Al, Rayaprolu S, Stewart H, Finger E, Volkening K, Seeley WW, Hatanpaa KJ, LomenHoerth C, Kertesz A, Bigio EH, Lippa C, Knopman DS, Kretzschmar HA, Neumann M, Caselli RJ, White CL, Mackenzie IR, Petersen RC, Strong MJ, Miller BL, Boeve BF, Uitti RJ, Boylan KB, Wszolek ZK, Graff-Radford NR, Dickson DW, Ross OA, Rademakers R. Length of normal alleles of C90RF72 GGGGCC repeat do not influence disease phenotype. Neurobiol Aging 2012;33:2950.e5-2950.e7.

16 Xi Z, Zinman L, Grinberg Y, Moreno D, Sato C, Bilbao JM, Ghani M, Hernández I, Ruiz A, Boada M, Morón FJ, Lang AE, Marras C, Bruni A, Colao R, Maletta RG, Puccio G, Rainero I, Pinessi L, Galimberti D, Morrison KE, Moorby C, Stockton JD, Masellis M, Black SE, Hazrati LN, Liang Y, van Haersma de With J, Fornazzari L, Villagra R, Rojas-Garcia R, Clarimón J, Mayeux R, Robertson J, St George-Hyslop P, Rogaeva E. Investigation of c9orf72 in 4 neurodegenerative disorders. Arch Neurol 2012;69:1583-90

17 Yeh TH, Lai SC, Weng YH, Kuo HC, Wu-Chou YH, Huang CL, Chen RS, Chang HC, Traynor B, Lu CS. Screening for C9orf72 repeat expansions in parkinsonian syndromes. Neurobiol Aging 2013;34:1311.e3-1311.e4.

18 Ogaki K, Li Y, Takanashi M, Ishikawa K, Kobayashi T, Nonaka T, Hasegawa M, Kishi M, Yoshino H, Funayama M, Tsukamoto T, Shioya K, Yokochi M, Imai H, Sasaki R, Kokubo Y, Kuzuhara S, Motoi Y, Tomiyama H, Hattori N. Analyses of the MAPT, PGRN, and C9orf72 mutations in Japanese patients with FTLD, PSP, and CBS. Parkinsonism Relat Disord 2013;19:15-20.

19 Tang M, Gu X, Wei J, Jiao B, Zhou L, Zhou Y, Weng L, Yan X, Tang B, Xu J, Shen L. Analyses MAPT, GRN, and C9orf72 mutations in Chinese patients with frontotemporal dementia. Neurobiol Aging 2016;46:235.e11-235.e15.

20 Simón-Sánchez J, Dopper EG, Cohn-Hokke PE, Hukema RK, Nicolaou N, Seelaar H, de Graaf JR, de Koning I, van Schoor NM, Deeg DJ, Smits M, Raaphorst J, van den Berg LH, Schelhaas HJ, De Die-Smulders CE, Majoor-Krakauer D, Rozemuller AJ, Willemsen R, Pijnenburg YA, Heutink P, van Swieten JC. The clinical and pathological phenotype of C9ORF72 hexanucleotide repeat expansions. Brain 2012;135:723-35.

21 Schottlaender LV, Polke JM, Ling H, MacDoanld ND, Tucci A, Nanji T, Pittman A, de Silva R, Holton JL, Revesz T, Sweeney MG, Singleton AB, Lees AJ, Bhatia KP, Houlden H. The analysis of C9orf72 repeat expansions in a large series of clinically and pathologically diagnosed cases with atypical parkinsonism. Neurobiol Aging 2015;36:1221. e1-1221.e6.

22 Abramycheva NY, Lysogorskaia EV, Stepanova MS, Zakharova MN, Kovrazhkina EA, Razinskaya OD, Smirnov AP, Maltsev AV, Ustyugov AA, Kukharsky MS, Khritankova IV, Bachurin SO, Cooper-Knock J, Buchman VL, Illarioshkin SN, Skvortsova VI, Ninkina N. C9ORF72 hexanucleotide repeat expansion in ALS patients from the Central European Russia population. Neurobiol Aging 2015;36:2908.e5-2908.e9.

23 Byrne S, Elamin M, Bede P, Shatunov A, Walsh C, Corr B, Heverin M, Jordan N, Kenna K, Lynch C, McLaughlin RL, Iyer PM, O'Brien C, Phukan J, Wynne B, Bokde AL, Bradley DG, Pender N, Al-Chalabi A, Hardiman O. Cognitive and clinical characteristics of patients with amyotrophic lateral sclerosis carrying a C9orf72 repeat expansion: a population-based cohort study. Lancet Neurol 2012;11:232-40.

24 Debray S, Race V, Crabbé V, Herdewyn S, Matthijs G, Goris A, Dubois B, Thijs V, Robberecht W, Van Damme P. Frequency of C9orf72 repeat expansions in amyotrophic lateral sclerosis: a Belgian cohort study. Neurobiol Aging 2013;34:2890.e7-2890. e12.

25 He J, Tang L, Benyamin B, Shah S, Hemani G, Liu R, Ye S, Liu X, Ma Y, Zhang H, Cremin K, Leo P, Wray NR, Visscher PM, Xu H, Brown MA, Bartlett PF, Mangelsdorf M, Fan D. C9orf72 hexanucleotide repeat expansions in Chinese sporadic amyotrophic lateral sclerosis. Neurobiol Aging 2015;36:2660.e1-2660.e8.

26 Jang JH, Kwon MJ, Choi WJ, Oh KW, Koh SH, Ki CS, Kim SH. Analysis of the C9orf72 hexanucleotide repeat expansion in Korean patients with familial and sporadic amyotrophic lateral sclerosis. Neurobiol Aging 2013;34:1311.e7-1311.e9.

27 Konno T, Shiga A, Tsujino A, Sugai A, Kato T, Kanai K, Yokoseki A, Eguchi H, Kuwabara S, Nishizawa M, Takahashi H, Onodera O. Japanese amyotrophic lateral sclerosis patients with GGGGCC hexanucleotide repeat expansion in C90RF72. J Neurol Neurosurg Psychiatry 2013;84:398-401.

28 Mok KY, Koutsis G, Schottlaender LV, Polke J, Panas M, Houlden H. High frequency of the expanded C9ORF72 hexanucleotide repeat in familial and sporadic Greek ALS patients. Neurobiol Aging 2012;33:1851.e1-1851.e5.

29 Ogaki K, Li Y, Atsuta N, Tomiyama H, Funayama M, Watanabe H, Nakamura R, Yoshino H, Yato S, Tamura A, Naito Y, Taniguchi A, Fujita K, Izumi Y, Kaji R, Hattori N, Sobue G. Japanese Consortium for Amyotrophic Lateral Sclerosis research (JaCALS). Analysis of C9orf72 repeat expansion in 563 japanese patients with amyotrophic lateral sclerosis. Neurobiol Aging 2012;33:2527.e11-16.

30 Akimoto C, Forsgren L, Linder J, Birve A, Backlund I, Andersson J, Nilsson AC, Alstermark H, Andersen PM. No GGGGCC-hexanucleotide repeat expansion in C9ORF72 in parkinsonism patients in Sweden. Amyotroph Lateral Scler Frontotemporal Degener 2013;14:26-9.

31 Dejesus-Hernandez M, Rayaprolu S, Soto-Ortolaza Al, Rutherford NJ, Heckman MG, Traynor S, Strongosky A, Graff-Radford N, Van Gerpen J, Uitti RJ, Shih JJ, Lin SC, Wszolek ZK, Rademakers R, Ross OA. Analysis of the C9orf72 repeat in Parkinson's disease, essential tremor and restless legs syndrome. Parkinsonism Relat Disord 2013;19:198-201.

32 Harms MB, Neumann D, Benitez BA, Cooper B, Carrell D, Racette BA, Perlmutter IS, Goate A, Cruchaga C. Parkinson disease is not associated with C9ORF72 repeat expansions. Neurobiol Aging 2013:34:1519.e1-1519.e2.

33 Lesage S, Le Ber I, Condroyer C, Broussolle E, Gabelle A, Thobois S, Pasquier F, Mondon K, Dion PA, Rochefort D, Rouleau GA, Dürr A, Brice A. French Parkinson's Disease Genetics Study Group. C9orf72 repeat expansions are a rare genetic cause of parkinsonism. Brain 2013;136:385-91.

34 Nuytemans K, Bademci G, Kohli MM, Beecham GW, Wang L, Young Jl, Nahab F, Martin ER, Gilbert JR, Benatar M, Haines JL, Scott WK, Züchner S, Pericak-Vance MA, Vance JM. C9ORF72 intermediate repeat copies are a significant risk factor for Parkinson disease. Ann Hum Genet 2013;77:351-63.

35 Majounie E, Renton AE, Mok K, Dopper EG, Waite A, Rollinson S, Chiò A, Restagno G, Nicolaou N, Simon-Sanchez J, van Swieten JC, Abramzon Y, Johnson JO, Sendtner M, Pamphlett R, Orrell RW, Mead S, Sidle KC, Houlden H, Rohrer JD, Morrison KE, Pall H, Talbot K, Ansorge O, Hernandez DG, Arepalli S, Sabatelli M, Mora G, Corbo M, Giannini F, Calvo A, Englund E, Borghero G, Remes AM, Remes AM, Laaksovirta H, Van Deerlin VM, Trojanowski JQ, Van Deerlin VM, Lu CS, Nalls MA, Drory VE, Lu CS, Yeh TH, Le Ber I, Takahashi Y, Tsuji S, Le Ber I, Brice A, Drepper C, Williams N, Kirby J, Shaw P, Hardy J, Tienari PJ, Heutink P, Morris HR, Pickering-Brown S, Traynor BJ.Frequency of the C9orf72 hexanucleotide repeat expansion in patients with amyotrophic lateral sclerosis and frontotemporal dementia: a cross-sectional study. Lancet Neurol 2012;11:323-30

36 Daoud H, Noreau A, Rochefort D, Paquin-Lanthier G, Gauthier MT, Provencher P, Pourcher E, Dupré N, Chouinard S, Jodoin N, Soland V, Fon EA, Dion PA, Rouleau GA. Investigation of C9orf72 repeat expansions in Parkinson's disease. Neurobiol Aging 2013;34:1710.e7-1710.e9.

37 Nuytemans K, Inchausti V, Beecham GW, Wang L, Dickson DW, Trojanowski JQ, Lee VM, Mash DC, Frosch MP, Foroud TM, Honig LS, Montine TJ, Dawson TM, Martin ER, Scott WK, Vance JM. Absence of C9ORF72 expanded or intermediate repeats in autopsy-confirmed Parkinson's disease. Mov Disord 2014;29:827-30.

38 Theuns J, Verstraeten A, Sleegers K, Wauters E, Giijselinck I, Smolders S, Crosiers D, Corsmit E, Elinck E, Sharma M, Krüger R, Lesage S, Brice A, Chung SJ, Kim MJ, Kim YJ, Ross OA, Wszolek ZK, Rogaeva E, Xi Z, Lang AE, Klein C, Weissbach A, Mellick GD, 
Silburn PA, Hadjigeorgiou GM, Dardiotis E, Hattori N, Ogaki K, Tan EK, Zhao Y, Aasly J, Valente EM, Petrucci S, Annesi G, Quattrone A, Ferrarese C, Brighina L, Deutschländer A, Puschmann A, Nilsson C, Garraux G, LeDoux MS, Pfeiffer RF, Boczarska-Jedynak M, Opala G, Maraganore DM, Engelborghs S, De Deyn PP, Cras P, Cruts M, Van Broeckhoven C. GEO-PD Consortium. Global investigation and meta-analysis of the C9orf72 (G4C2)n repeat in Parkinson disease. Neurology 2014;83:1906-13.

39 Scholz SW, Majounie E, Revesz T, Holton JL, Okun MS, Houlden H, Singleton AB. Multiple system atrophy is not caused by C9orf72 hexanucleotide repeat expansions. Neurobiol Aging 2015;36:1223.e1-1223.e2.

40 Geiger JT, Arthur KC, Dawson TM, Rosenthal LS, Pantelyat A, Albert M, Hillis AE, Crain B, Pletnikova O, Troncoso JC, Scholz SW. C9orf72 Hexanucleotide Repeat Analysis in Cases with Pathologically Confirmed Dementia with Lewy Bodies. Neurodegener Dis 2016;16:370-2.

41 Kun-Rodrigues C, Ross OA, Orme T, Shepherd C, Parkkinen L, Darwent L, Hernandez D, Ansorge O, Clark LN, Honig LS, Marder K, Lemstra A, Scheltens P, van der Flier W, Louwersheimer E, Holstege H, Rogaeva E, St George-Hyslop P, Londos E, Zetterberg H, Barber I, Braae A, Brown K, Morgan K, Maetzler W, Berg D, Troakes C, Al-Sarraj S, Lashley T, Holton J, Compta Y, Van Deerlin V, Trojanowski JQ, Serrano GE, Beach TG, Clarimon J, Lleó A, Morenas-Rodríguez E, Lesage S, Galasko D, Masliah E, Santana I, Diez M, Pastor P, Tienari PJ, Myllykangas L, Oinas M, Revesz T, Lees A, Boeve BF, Petersen RC, Ferman TJ, Escott-Price V, Graff-Radford N, Cairns NJ, Morris JC, Stone DJ, Pickering-Brown S, Mann D, Dickson DW, Halliday GM, Singleton A, Guerreiro R, Bras J. Analysis of C9orf72 repeat expansions in a large international cohort of dementia with Lewy bodies. Neurobiol Aging 2017;49:214.e13-214.e15.

42 Cannas A, Solla P, Borghero G, Floris GL, Chio A, Mascia MM, Modugno N, Muroni A, Orofino G, Di Stefano F, Calvo A, Moglia C, Restagno G, Meloni M, Farris R, Ciaccio D, Puddu R, Vacca MI, Melis R, Murru MR, Tranquilli S, Corongiu D, Rolesu M, Cuccu S, Marrosu MG, Marrosu F. C9ORF72 intermediate repeat expansion in patients affected by atypical parkinsonian syndromes or Parkinson's disease complicated by psychosis or dementia in a Sardinian population. J Neurol 2015;262:2498-503.

43 Rollinson S, Halliwell N, Young K, Callister JB, Toulson G, Gibbons L, Davidson YS, Robinson AC, Gerhard A, Richardson A, Neary D, Snowden J, Mann DMA, PickeringBrown SM. Analysis of the hexanucleotide repeat in C9ORF72 in Alzheimer's disease. Neurobiol Aging 2012;33:1846.e5-1846.e6.

44 Kohli MA, John-Williams K, Rajbhandary R, Naj A, Whitehead P, Hamilton K, Carney RM, Wright C, Crocco E, Gwirtzman HE, Lang R, Beecham G, Martin ER, Gilbert J, Benatar M, Small GW, Mash D, Byrd G, Haines JL, Pericak-Vance MA, Züchner S. Repeat expansions in the C9ORF72 gene contribute to Alzheimer's disease in Caucasians. Neurobiol Aging 2013;34:1519.e5-1519.e12.

45 Cacace R, Van Cauwenberghe C, Bettens K, Giijselinck I, van der Zee J, Engelborghs S, Vandenbulcke M, Van Dongen J, Bäumer V, Dillen L, Mattheijssens M, Peeters K, Cruts M, Vandenberghe R, De Deyn PP, Van Broeckhoven C, Sleegers K. C9orf72 G4C2 repeat expansions in Alzheimer's disease and mild cognitive impairment. Neurobiol Aging 2013;34:1712.e1-1712.e7.

46 Galimberti D, Reif A, Dell'osso B, Kittel-Schneider S, Leonhard C, Herr A, Palazzo C, Villa C, Fenoglio C, Serpente M, Cioffi SMG, Prunas C, Paoli RA, Altamura AC. Scarpini E. C9ORF72 hexanucleotide repeat expansion is a rare cause of schizophrenia. Neurobiol Aging 2014

47 Solje E, Miettunen J, Marttila R, Helisalmi S, Laitinen M, Koivumaa-Honkanen H, Isohanni M, Hiltunen M, Jääskeläinen E, Remes AM. The C9ORF72 expansion sizes in patients with psychosis: a population-based study on the Northern Finland Birth Cohort 1966. Psychiatr Genet 2016;26:92-4.

48 Fahey C, Byrne S, McLaughlin R, Kenna K, Shatunov A, Donohoe G, Gill M, Al-Chalabi A, Bradley DG, Hardiman O, Corvin AP, Morris DW. Analysis of the hexanucleotide repeat expansion and founder haplotype at C9ORF72 in an Irish psychosis casecontrol sample. Neurobiol Aging 2014;35:1510.e1-1510.e5.

49 Smith BN, Newhouse S, Shatunov A, Vance C, Topp S, Johnson L, Miller J, Lee Y, Troakes C, Scott KM, Jones A, Gray I, Wright J, Hortobágyi T, Al-Sarraj S, Rogelj B, Powell J, Lupton M, Lovestone S, Sapp PC, Weber M, Nestor PJ, Schelhaas HJ, Asbroek AA, Silani V, Gellera C, Taroni F, Ticozzi N, Van den Berg L, Veldink J, Van Damme P, Robberecht W, Shaw PJ, Kirby J, Pall H, Morrison KE, Morris A, de Belleroche J, Vianney de Jong JM, Baas F, Andersen PM, Landers J, Brown RH, Weale ME, Al-Chalabi A, Shaw CE. The C9ORF72 expansion mutation is a common cause of ALS+/-FTD in Europe and has a single founder. Eur I Hum Genet 2013;21:102-8.

50 Mok K, Traynor BJ, Schymick J, Tienari PJ, Laaksovirta H, Peuralinna T, Myllykangas L, Chiò A, Shatunov A, Boeve BF, Boxer AL, DeJesus-Hernandez M, Mackenzie IR, Waite A, Williams N, Morris HR, Simón-Sánchez J, van Swieten JC, Heutink P, Restagno G, Mora G, Morrison KE, Shaw PJ, Rollinson PS, Al-Chalabi A, Rademakers R, PickeringBrown S, Orrell RW, Nalls MA, Hardy J. Chromosome 9 ALS and FTD locus is probably derived from a single founder. Neurobiol Aging 2012;33:209.e3-209.e8.

51 van der Zee J, Gijselinck I, Dillen L, Van Langenhove T, Theuns J, Engelborghs S, Philtjens S, Vandenbulcke M, Sleegers K, Sieben A, Bäumer V, Maes G, Corsmit E, Borroni B, Padovani A, Archetti S, Perneczky R, Diehl-Schmid J, de Mendonça A,
Miltenberger-Miltenyi G, Pereira S, Pimentel J, Nacmias B, Bagnoli S, Sorbi S, Graff C, Chiang HH, Westerlund M, Sanchez-Valle R, Llado A, Gelpi E, Santana I, Almeida MR, Santiago B, Frisoni G, Zanetti O, Bonvicini C, Synofzik M, Maetzler W, Vom Hagen JM, Schöls L, Heneka MT, Jessen F, Matej R, Parobkova E, Kovacs GG, Ströbel T, Sarafov S, Tournev I, Jordanova A, Danek A, Arzberger T, Fabrizi GM, Testi S, Salmon E, Santens P, Martin JJ, Cras P, Vandenberghe R, De Deyn PP, Cruts M, Van Broeckhoven C, van der Zee J, Gijselinck I, Dillen L, Van Langenhove T, Theuns J, Philtjens S, Sleegers K, Bäumer V, Maes G, Corsmit E, Cruts M, Van Broeckhoven C, van der Zee J, Gijselinck I, Dillen L, Van Langenhove T, Philtjens S, Theuns J, Sleegers K, Bäumer V, Maes G, Cruts $M$, Van Broeckhoven C, Engelborghs S, De Deyn PP, Cras P, Engelborghs S, De Deyn PP, Vandenbulcke M, Vandenbulcke M, Borroni B, Padovani A, Archetti S, Perneczky R, Diehl-Schmid J, Synofzik M, Maetzler W, Müller Vom Hagen J, Schöls L, Synofzik M, Maetzler W, Müller Vom Hagen J, Schöls L, Heneka MT, Jessen F, Ramirez A, Kurzwelly D, Sachtleben C, Mairer W, de Mendonça A, Miltenberger-Miltenyi G, Pereira S, Firmo C, Pimentel J, Sanchez-Valle R, Llado A, Antonell A, Molinuevo J, Gelpi E, Graff C, Chiang HH, Westerlund M, Graff C, Kinhult Ståhlbom A, Thonberg H, Nennesmo I, Börjesson-Hanson A, Nacmias B, Bagnoli S, Sorbi S, Bessi V, Piaceri I, Santana I, Santiago B, Santana I, Helena Ribeiro M, Rosário Almeida M, Oliveira C, Massano J, Garret C, Pires P, Frisoni G, Zanetti O, Bonvicini C, Sarafov S, Tournev I, Jordanova A, Tournev I, Kovacs GG, Ströbel T, Heneka MT, Jessen F, Ramirez A, Kurzwelly D, Sachtleben C, Mairer W, Jessen F, Matej R, Parobkova E, Danel A, Arzberger T, Maria Fabrizi G, Testi S, Ferrari S, Cavallaro T, Salmon E, Santens P, Cras P. European EarlyOnset Dementia Consortium. A pan-European study of the C9orf72 repeat associated with FTLD: geographic prevalence, genomic instability, and intermediate repeats. Hum Mutat 2013;34:363-73

52 Xi Z, Zinman L, Moreno D, Schymick J, Liang Y, Sato C, Zheng Y, Ghani M, Dib S, Keith J, Robertson J, Rogaeva E. Hypermethylation of the CpG island near the G4C2 repeat in ALS with a C9orf72 expansion. Am J Hum Genet 2013;92:981-9.

53 Gijselinck I, Van Mossevelde S, van der Zee J, Sieben A, Engelborghs S, De Bleecker J, Ivanoiu A, Deryck O, Edbauer D, Zhang M, Heeman B, Bäumer V, Van den Broeck M, Mattheijssens M, Peeters K, Rogaeva E, De Jonghe P, Cras P, Martin JJ, de Deyn PP, Cruts M, Van Broeckhoven C. The C9orf72 repeat size correlates with onset age of disease, DNA methylation and transcriptional downregulation of the promoter. $\mathrm{Mol}$ Psychiatry 2016;21:1112-24.

54 van Blitterswijk M, DeJesus-Hernandez M, Niemantsverdriet E, Murray ME, Heckman MG, Diehl NN, Brown PH, Baker MC, Finch NA, Bauer PO, Serrano G, Beach TG, Josephs KA, Knopman DS, Petersen RC, Boeve BF, Graff-Radford NR, Boylan KB, Petrucelli L, Dickson DW, Rademakers R. Association between repeat sizes and clinical and pathological characteristics in carriers of C9ORF72 repeat expansions (Xpansize-72): a cross-sectional cohort study. Lancet Neurol 2013;12:978-88.

55 Dols-Icardo 0, García-Redondo A, Rojas-García R, Sánchez-Valle R, Noguera A, Gómez-Tortosa E, Pastor P, Hernández I, Esteban-Pérez J, Suárez-Calvet M, AntónAguirre S, Amer G, Ortega-Cubero S, Blesa R, Fortea J, Alcolea D, Capdevila A, Antonell A, Lladó A, Muñoz-Blanco JL, Mora JS, Galán-Dávila L, Rodríguez De Rivera FJ, Lleó A, Clarimón J. Characterization of the repeat expansion size in C9orf72 in amyotrophic lateral sclerosis and frontotemporal dementia. Hum Mol Genet 2014;23:749-54.

56 Fratta P, Polke JM, Newcombe J, Mizielinska S, Lashley T, Poulter M, Beck J, Preza E, Devoy A, Sidle K, Howard R, Malaspina A, Orrell RW, Clarke J, Lu CH, Mok K, Collins T, Shoaii M, Nanji T, Wray S, Adamson G, Pittman A, Renton AE, Traynor BJ, Sweeney MG, Revesz T, Houlden H, Mead S, Isaacs AM, Fisher EM. Screening a UK amyotrophic lateral sclerosis cohort provides evidence of multiple origins of the C9orf72 expansion. Neurobiol Aging 2015;36:546.e1-546.e7.

57 Nordin A, Akimoto C, Wuolikainen A, Alstermark H, Jonsson P, Birve A, Marklund SL, Graffmo KS, Forsberg K, Brännström T, Andersen PM. Extensive size variability of the GGGGCC expansion in C9orf72 in both neuronal and non-neuronal tissues in 18 patients with ALS or FTD. Hum Mol Genet 2015;24:3133-42.

58 Gami P, Murray C, Schottlaender L, Bettencourt Concei?? o, De Pablo Fernandez E, Mudanohwo E, Mizielinska S, Polke JM, Holton JL, Isaacs AM, Houlden H, Revesz T, Lashley T. A 30-unit hexanucleotide repeat expansion in C9orf72 induces pathological lesions with dipeptide-repeat proteins and RNA foci, but not TDP-43 inclusions and clinical disease. Acta Neuropathol 2015;130:599-601.

59 Akimoto C, Volk AE, van Blitterswijk M, Van den Broeck M, Leblond CS, Lumbroso S, Camu W, Neitzel B, Onodera O, van Rheenen W, Pinto S, Weber M, Smith B, Proven M, Talbot K, Keagle P, Chesi A, Ratti A, van der Zee J, Alstermark H, Birve A, Calini D, Nordin A, Tradowsky DC, Just W, Daoud H, Angerbauer S, DeJesus-Hernandez M, Konno T, Lloyd-Jani A, de Carvalho M, Mouzat K, Landers JE, Veldink JH, Silani V, Gitler $A D$, Shaw CE, Rouleau GA, van den Berg LH, Van Broeckhoven C, Rademakers R, Andersen PM, Kubisch C. A blinded international study on the reliability of genetic testing for GGGGCC-repeat expansions in C9orf72 reveals marked differences in results among 14 laboratories. J Med Genet 2014;51:419-24.

60 Cleary EM, Pal S, Azam T, Moore DJ, Swingler R, Gorrie G, Stephenson L, Colville S, Chandran S, Porteous M, Warner JP. Improved PCR based methods for detecting C9orf72 hexanucleotide repeat expansions. Mol Cell Probes 2016;30:218-24. 